\title{
ACTUAL PROBLEMS OF FINANCIAL CONTROL OF LOCAL GOVERNMENT
}

\author{
Elena Kushlak \\ Bukovina University, Chernivtsi, Ukraine \\ () MESTE NGO \\ JEL Category: E62, H76
}

\begin{abstract}
Transformation processes in Ukrainian society necessitate addressing important task - the creation of the state of effective financial and budgetary system and effective mechanisms for its further improvement. In the organization of system of financial control in Ukraine there are a number of problems that reduce the level of financial budgetary discipline in the regions. This requires a rethinking of the role of the state in the exercise of financial control in general and local budgets in particular, the concept of external and internal financial control interrelations of structural elements of state control as an integrated system. The paper highlights the main bottlenecks of the state financial control of local government in Ukraine and the basic problems of the current system in Ukraine state financial control, which subsequently lead to inefficient management of the economy and public finances. The study suggested solutions. Based on the priority of the state policy in the context of Ukraine's accession to the EU, we can say that an important aspect of this process is the adaptation of the system of state financial control to EU requirements. There are given some suggestions to improve the effectiveness of the system of financial control activities of local government. Here is highlighted the need to review approaches of creating a modern system of public and financial control in Ukraine, taking into account requirements of European Union and internal features of the state.
\end{abstract}

Keywords: state financial control, local governments' internal financial control, external independent control, governance, local budgets, reform, transformation

\section{PROBLEMS OF FINANCIAL CONTROL AT THE REGIONAL AND LOCAL LEVEL}

Updating survey of state financial control at the local level is to identify the problem areas of the field and finding ways to address these issues, especially concerning the formation and function of the optimal variant of the system of financial control.

Address of the author:

Elena Kushlak

邦" kushlak.aliona@gmail.com
The system of financial control, which is essential for the economic development of Ukraine shall provide as improving the efficiency of formation of financial resources and their allocation, distribution and use. State financial control is one of the important functions of the government as an instrument of implementation of financial policies, ensures the formation and effective use of financial resources of the state for achieving its objectives in the field of finance. It seeks to identify any deviations from the agreed standards of legality, appropriateness and effectiveness of financial management and property of the state, and in case of such deviations provides timely take appropriate corrective and preventive measures. It 
should be noted that from the way the system is built in the country public financial control is largely dependent, on the one hand, the credibility of the state as their own citizens and foreign communities, and on the other - economic growth, the region in general, and economic subjects in particular. The efficiency of public financial control depends on the economic and political well-being of the nation.

However, the system of financial control, built in Ukraine does not provide for an adequate level of fiscal discipline as a whole in the state and regional level in particular. This is due to a number of problems that create growth trends in the number and volume of major financial irregularities. This system operates without the existence of a basic law that establishes the basic concepts in this area, clearly divides tasks, functions and powers between the state and local authorities, governing relations between subjects and objects of control, responsibility and independence determines appropriate law enforcement officials.

The Budget Code of Ukraine (Zakon, Byudzhetnyy kodeks Ukrayiny, 2010) does not resolve these issues. Unsystematic result in the legal field has become unbalanced system of bodies providing public financial control and audit (Hilobok, 2009, p. 122).

Approved the concept of public internal financial control provides a "warped scenario" development that could lead to the continuation of the practice of fraud and financial irregularities, primarily in the public sector. In the government's concept of public internal financial control, local authorities referred to the public sector.

However, the Law of Ukraine "On Local SelfGovernment" in no way considers the functions and powers of local government in the state sector.

The Law of Ukraine "On Local Self-Government" determined that the state financial control over the activities of agencies and officials of local selfgovernment can only be made on the basis and within the limits and in the manner specified by the Constitution of Ukraine and laws of Ukraine, and should not lead to interference by government or their officials in the implementation of local selfgovernment granted them their powers. (Zakon, Zakon Ukraini Pro derzhavne regljuvannja u sferi komunal'nih poslug, 2011)

At the same time it should also be noted that the Cabinet of Ministers of Ukraine "On organization of local state administrations" provided in the device structure administrations separate entity, which would have relied function of internal financial control. Therefore, the local authorities are not interested in the organization of internal financial control in the region, leading to the existence of ineffective internal controls over the use of local budgets and transfers.

The current model of state financial control must comply with the principle of decentralization. Therefore, it is necessary to build a system based on the development of internal management and control at the regional level. This is the creation of local governments at all levels of the system of internal controls over the use of local budgets and public property and of external control at the regional and local levels (Stefanyuk, 2009, pp. 3839).

According to current legislation of Ukraine status report fiscal discipline is not defined as part of reporting on the state and local budgets and is not considered by the Verkhovna Rada of Ukraine and the relevant councils. As for the reports on the implementation of local budgets, then they do not prepare conclusions external (independent) audit institution, and consider only committees on Budget respective councils.

Summary results of audited reports, which are sent by the Control and Audit Office Verkhovna Rada of Ukraine and the Ministry of Finance are not approved and it is not accepted by the relevant decision, and only come to the attention of authorities. This indicates a low level of objectivity in the assessment of fiscal discipline in Ukraine and inefficient procedures and mechanism for reporting.

Under the provisions of the Constitution of Ukraine (Article 140) Local government is the right of territorial communities to solve local issues within the laws of Ukraine. Local government is exercised by a territorial community in the manner 
prescribed by law, both directly and through local government: village, town and city councils and their executive bodies. Local government in Ukraine - is guaranteed by state law and the actual capacity of the territorial community independently or under the responsibility of authorities and local government officials to address issues of local importance within the Constitution and laws of Ukraine. Articles 142-145 of the Constitution of Ukraine (Konstytutsiya Ukrayiny, 2014) and the Law of Ukraine "On Local Self-Government in Ukraine" (2015) clearly defined responsibilities and powers of local government and are in no way related to the public sector. Only a few powers delegated authorities granted by the law to local governments may be regarded as a public authority. With respect to internal control, it should be noted that statutory enough of their own powers of local governments to provide domestic (municipal) control.

At the same time, the Law of Ukraine "On Local Self-Government" states that public oversight bodies and local government officials may be made only on the basis and within the limits and in the manner provided by the Constitution of Ukraine and laws of Ukraine, and should not lead the intervention of public authorities or their officials in the implementation of local selfgovernment granted them their powers.

In addition, the provisions of the Concept of imposing additional powers of the State Control and Revision Office of centralized internal audit and inspection centralized community property (property administrative units) contradict relevant provisions of the Law of Ukraine "On Property". Subjects of community property are administrative units in the face of regional, district, city, town and village councils. Management of such property on behalf of the people carrying out the relevant Council of People's Deputies. The legislation stipulates that the bodies authorized to manage state property monitor the effective use and safekeeping of the property entrusted to them. However, according to the concept central executive authority in the field of audit as the Control and Auditing Service and its territorial units shall be entitled, in fact, from the outside to interfere in the management of municipal property. This put the actions of local governments on public property, depending on the staff of the Control and Audit Office and led to increased confrontation between the authorities of different levels of government.

It may be reason to say "warped scenario" development embedded in the reform of public financial control, which launched currently in Ukraine. After analyzing the model that laid the basis for reform can predict subsequent risk of negative consequences of its implementation.

First, the maintenance of such a system will require substantial material and financial resources, both from the state and the taxpayer. Second, the combination of two different systems in nature, one of which aims to prevent the violation, and in case of - correct, and the second system is intended to identify the offender and punish him. This polarity approaches lead to deep conflict, both in the control system, and between subject and object controls.

Third, the accumulation of a large number of system types, forms and methods of control as obsolete (command-administrative) and modern, which will result in inefficiency and ineffectiveness of control measures.

The concept of public internal financial control is definitely very important and right step towards the reform of public financial control in Ukraine. It has many advantages in the case of successful realization should bring Ukraine closer to international requirements and standards and to facilitate the adaptation of national legislation with EU law.

Public financial control, as part of financial management falls far short of the reform of intergovernmental fiscal relations. There was a transfer of power in relation to a particular part of the budget resources to local governments, but did not materialize appropriate delegation of authority with respect to liability for poor management. Based on the priority of the state policy in the context of Ukraine's accession to the $\mathrm{EU}$, an important aspect in this process is the adaptation of the system of state financial control to EU requirements. This is a fulfillment of Ukraine requirements of Chapter 28, "Financial Control" document "Acquis communautaire" and the 
provisions of the Lima Declaration of Guidelines on control.

Necessary in the context of public administration reform, which started in Ukraine in general change approaches to the concept of "control" and bring it closer to the European interpretation. The monitoring system should be aimed at correcting violations and preventing them in the future. In addition, the system of financial control at the local level should be permanent. To build an effective system of financial control in Ukraine that provides a stable state of fiscal discipline in the region is possible only in the presence of effective internal control system in local authorities at all levels (regions, cities, villages, etc.), that the system of municipal financial control. For this purpose it is necessary to develop and approve in law present an updated model of the system of financial control in Ukraine.

\section{FINANCIAL CONTROL IN THE CONTEXT OF THE} TRANSFORMATION PROCESSES.

In order to address the shortcomings in the functioning of public financial control system is necessary to effect a change in priorities - from inspection of sanctions for offenses committed in the audit aimed at preventing violations and improving the management of budgetary resources by providing independent and objective advice.

It should be noted that the elimination of existing shortcomings in the functioning of public financial control and its transformation into a modern model with changing priorities and requirements in controlling the system needs reform.

General features of the most optimal and one that would meet the requirements of the EU model of financial control at the local level (municipal financial control) in Ukraine can be:

1. the independent financial control, independent control of the total revenues for all budget and spending of budget funds, including local budgets and transfers shall be made by the Accounting Chamber and its regional offices ;
2. internal financial control, monitoring of the timely and full collection of taxes and duties (mandatory payments) to all budgets Ministry of Finance, including the State Tax Administration, Customs Service of Ukraine within the ministry as well as other competent authorities power;

3. internal financial control, in terms of control over the use of local budgets and transfers from local budgets, internal control and audit services as part of local authorities (municipal control) and auditors in public institutions, in terms of controlling the use of transfers from the state budget local budgets - authorized representatives (state auditors) the Minister of Finance.

Specific measures to increase the number of inspections at the local level regulatory authorities will not result in a significant improvement of financial and budgetary discipline. In this regard, it is proposed to define the conceptual model on municipal financial control and the stages of its implementation and outline the laws and regulations that provide the legal framework and implement financial and economic analysis of the model.

The authorities must carry out a series of systematic measures that would allow to stabilize fiscal discipline at the local level. In particular, to:

1. develop and adopt a law on financial control and ethics for auditors.

2. prepare amendments to the Budget Code of Ukraine and the Code of Ukraine on Administrative Offences.

3. create an internal audit in the state of local authorities, in this case, to distinguish between the functions of inspection (audit) and audits.

4. take appropriate measures for the implementation of municipal financial control and audit at regional and local level.

5. strengthen the responsibility of managers at all levels of government and clearly establish its limits in the legislation.

6. establish a risk assessment during the state audit and financial management and transparent mechanism for planning of control measures. 
7. create conditions at the local level of training and retraining to meet the new qualification requirements and procedures. Implement appropriate education course to prepare public auditors.

8. develop a common reporting form and procedure of state financial control and audit local authorities.

9. statement fiscal discipline at the local level to include in the report on the implementation of the relevant budget.

10. create a single database of state financial control with the ability to use it locally.

It should be noted that the emphasis in modern terms had been made on reforming the system of internal control of the State. This is because the external control of public financial control Ukraine occupies an important place and is the most developed species, characterized by the highest level of centralization and fiscal direction. In contrast to the national system, at the heart of the control system put internal audit and internal control as components of public internal financial control, which allows you to create favorable conditions to avoid financial irregularities in the public sector, more efficient use of budget funds and state property, responsibility and accountability of managers enterprises, institutions and organizations in the public administration.

Today Ukraine is in the first stage of implementation of the European model of public internal state control. However, in recent years, our country has progressed quite significantly in the legislative and methodological adjustment of the national system of public internal financial control. That is why today is safe to say the presence of a coherent normative - legal framework at the state level governing the implementation and operation of public internal financial control in local organs of state and public sector.

The European experience shows that the organization of internal financial control is based on centralized and decentralized models.

When using any - any of the models needed to assess the specificity of public administration and development of public finances. Ukraine has not yet established a proper legal and methodological support the functioning of decentralized internal audit in public and public sector, as the initial implementation of internal audit in the public sector, we believe that it is feasible to introduce moderately centralized approach. European standards suggest the operation of such a model, even if it is contrary to the ideal decentralized model. In Ukraine, as in some countries in Eastern Europe, dominated by centralized model of public internal financial control elements decentralized in the previous exercise control. Address major economic problems in public finances depends on power management solutions, financial support, identification and achievement of major objectives and internal control systems as an effective control system should ensure the implementation of state policy in the sphere of land relations. Taking into account the recommendations of the European Community, the initial stage of the internal control system in Ukraine should be formed from moderately centralized model.

\section{WAYS TO IMPROVE FINANCIAL CONTROL AT THE REGIONAL LEVEL}

After analyzing the system of state financial control at the local level, we can say about the lack of effectiveness of the current system of financial control, including control of local financial authorities. The primary need is to improve legislation on financial control at the local level.

One of the ways of improvement of financial control should be to increase the effectiveness of preventive control on the part of the Treasury, in coordination with the executive power and state tax administration (Bubenko \& Butenko, 2008).

However, it is useful to enable local financial authorities also independently control the financial activities of local government, primarily through the establishment of the structure of their financial departments to monitor the collection of local taxes and fees.

It should also improve methods of control procedures, replace outdated methods of retrospective control by modern methods that are 
not aimed at detecting violations and prevent them in the future.

All this will improve the activity of control subjects, their interaction will facilitate the coordination of financial control at the local level, and will ensure that local budgets and adherence to fiscal discipline.

Thus, to be formed almost new paradigm of the control system of the state, which should be not only the transformation of forms of control, and system coordination and control of the transition of control over the use to monitor the effectiveness of the use of public resources shift from the principle of criminal control of preventive and counseling (Basantsov, 2011, p. 13).

This, in turn, promote the rational use of public resources, strengthen fiscal discipline, rapid response to potential hazards that can lead to financial irregularities, and will ensure the efficiency of the fiscal system as a whole.

\section{WORKS CITED}

Basantsov, Y. (2011). Derzhavni finansovyy audyt: konspekt lektsiy dlya pohlyblenoho vyvchennya predmeta "Audyt". Sumy: Sums'kyy derzhavnyy universytet.

Bubenko, I., \& Butenko, V. (2008). Problemy finansovoho kontrolyu na rehional'nomu rivni. Ekonomichnyy prostir(11), 51-56.

Hilobok, Y. (2009). The problems of financial control at the regional and local level. Money, finance and credit(4), 121-123.

Konstytutsiya Ukrayiny. (2014, May 15). Konstytutsiya Ukrayiny (Vidomosti Verkhovnoyi Rady Ukrayiny (VVR), 1996, № 30, st. 141). Retrieved from Verkhovna Rada Ukrayiny: http://zakon4.rada.gov.ua/laws/show/254\%D0\%BA/96-\%D0\%B2\%D1\%80

Stefanyuk, I. (2009). Derzhavnyy finansovyy kontrol': problemy identyfikatsiyi i vyznachennya systemy. Finansy Ukrayiny(11), 28-34.

Zakon. (2010). Byudzhetnyy kodeks Ukrayiny. Vidomosti Verkhovnoyi Rady Ukrayiny (VVR)(50-51), 572. Retrieved from http://www.profiwins.com.ua/legislation/kodeks/927.html

Zakon. (2011, Avg 07). Zakon Ukraini Pro derzhavne regljuvannja u sferi komunal'nih poslug. Retrieved from Verkhovna Rada Ukraini: http://zakon2.rada.gov.ua/laws/show/2479-17/ed20120601

Zakon. (2015, Mar 05). Zakon Ukrayiny pro mistseve samovryaduvannya v Ukrayini (Vidomosti Verkhovnoyi Rady Ukrayiny (VVR), 1997, № 24, st.170). Retrieved from Verkhovna Rada Ukrayiny: http://zakon4.rada.gov.ua/laws/show/280/97-\%D0\%B2\%D1\%80

Received for publication: $\quad$ 03.04.2014

Revision received: $\quad 27.02 .2015$

Accepted for publication: $\quad 27.03 .2015$

\section{How to cite this article?}

Style - APA Sixth Edition:

Kushlak, E. (2013, July 15). Actual problems of financial control of local government. (Z. Čekerevac, Ed.) MEST Journal, 3(2), 72-78. doi:10.12709/mest.03.03.02.08

Style - Chicago Sixteenth Edition:

Kushlak, Elena. 2013. "Actual problems of financial control of local government." Edited by Zoran Čekerevac. MEST Journal (MESTE) 3 (2): 72-78. doi:10.12709/mest.03.03.02.08. 
Kushlak E. Problems of financial control of local government

MEST Journal Vol. 3 No. 2 pp. 72-78

Style - GOST Name Sort:

Kushlak Elena Actual problems of financial control of local government [Journal] // MEST Journal / ed. Čekerevac Zoran. - Belgrade : MESTE, July 15, 2013. - 2 : Vol. 3. - pp. 72-78.

Style - Harvard Anglia:

Kushlak, E., 2013. Actual problems of financial control of local government. MEST Journal, 15 July, 3(2), pp. $72-78$.

Style - ISO 690 Numerical Reference:

Actual problems of financial control of local government. Kushlak, Elena. [ed.] Zoran Čekerevac. 2, Belgrade : MESTE, July 15, 2013, MEST Journal, Vol. 3, pp. 72-78. 